\title{
Exopolysaccharides Producing Lactic Acid Bacteria in Wine and Other Fermented Beverages: For Better or for Worse?
}

\author{
Maria Dimopoulou ${ }^{1}$ (D) and Marguerite Dols-Lafargue ${ }^{2, *(D)}$ \\ 1 Department of Wine, Vine and Beverage Sciences, School of Food Science, University of West Attica, \\ Ag. Spyridonos str, Egaleo, 12243 Athens, Greece; mdimopoulou@uniwa.gr \\ 2 Unité de Recherche CEnologie EA 4577, University of Bordeaux, ISVV, USC 1366 INRA, Bordeaux INP, \\ F-33140 Villenave d'Ornon, France \\ * Correspondence: dols@enscbp.fr
}

check for updates

Citation: Dimopoulou, M. Dols-Lafargue, M. Exopolysaccharides Producing Lactic Acid Bacteria in Wine and Other Fermented Beverages: For Better or for Worse? Foods 2021, 10, 2204 https://doi.org/10.3390/foods 10092204

Academic Editors: Paloma López and Maria Teresa Dueñas

Received: 23 August 2021

Accepted: 15 September 2021

Published: 17 September 2021

Publisher's Note: MDPI stays neutral with regard to jurisdictional claims in published maps and institutional affiliations.

Copyright: (c) 2021 by the authors. Licensee MDPI, Basel, Switzerland. This article is an open access article distributed under the terms and conditions of the Creative Commons Attribution (CC BY) license (https:// creativecommons.org/licenses/by/ $4.0 /)$.

\begin{abstract}
Lactic acid bacteria (LAB) from fermented beverages such as wine, cider and beer produce a wide range of exopolysaccharides (EPS) through multiple biosynthetic pathways. These extracellular polysaccharides constitute key elements for bacterial species adaptation to such anthropic processes. In the food industry, LAB polysaccharides have been widely studied for their rheological, functional and nutritional properties; however, these have been poorly studied in wine, beer and cider until recently. In this review, we have gathered the information available on these specific polysaccharide structure and, biosynthetic pathways, as well as the physiology of their production. The genes associated with EPS synthesis are also presented and compared. Finally, the possible role of EPS for bacterial survival and spread, as well as the risks or possible benefits for the winemaker and the wine lover, are discussed.
\end{abstract}

Keywords: lactic acid bacteria; wine; exopolysaccharides; fermented beverages

\section{Introduction}

Lactic acid bacteria (LAB) form a large group of bacteria, and are widely used throughout the world for the biotransformation of animal and plant resources. From very early on, they were valued to preserve and improve the organoleptic or nutritional properties of many foods. This is also the case in fermented beverages, where many distinct genera and species have been described [1]. However, not all species are found in all beverages. Species distribution seems rather specific to a particular type of fermented drink. Furthermore, $\mathrm{LAB}$ are sometimes hardly detectable in fruits and become dominant at certain steps in the production process. In fact, in wine and cider, LAB develops after the yeasts first drive alcoholic fermentation (AF). At the end of AF, upon lysis of the yeasts, the medium contains high levels of ethanol and very few residual sugars; it is acidic. Only certain species have been found to resist this process, including LAB of the genera Lactobacillus, Pediococcus, Oenococcus and Leuconostoc [2]. These bacteria multiply by consuming the elements left by the yeasts (sugars, acids). Depending on the metabolic pathways taken to break down the sugars, they produce either only lactic acid (homofermentative bacteria) or a mixture of lactic acid and acetate or ethanol (heterofermentative bacteria) [2]. However, the main visible transformation carried out by lactic acid bacteria in wine and cider is the conversion of the L-malic acid present into L-lactic acid and $\mathrm{CO}_{2}$. Although this is not fermentation sensu stricto, this reaction is called malolactic fermentation (MLF). MLF is important for three reasons [3]: (i) the transformation of malic acid (di-acid) into lactic acid (monoacid) softens the beverage, reducing its total acidity; (ii) the growth of bacteria is accompanied by the consumption of the residual substrates of the medium, which limits the risk of development of the spoilage flora during storage and aging and (iii) the release of aromas (from grapes, apples, yeasts or wood precursors) and the production of secondary metabolites by 
bacteria contribute to the final sensorial properties of the wine [4-6] In the same way, LAB also modulate the ciders final quality $[7,8]$.

The success of MLF relies on the ability of indigenous LAB to survive and develop under particularly hostile physicochemical conditions. Only the most resistant LAB are selected. Though MLF can also be carried out by genera other than Oenococcus $[4,9]$ most often, Oenococcus oeni becomes the dominant species and the main driver of MLF in temperate-zone wines or ciders, although it is hardly detected on the fruits $[4,8,10]$. The bacterial strains found in ciders and wines are different, suggesting that a form of domestication has occurred within the species. Other species of the genus Oenococcus are found in fermented products made from sugar cane (O. alcolitolerans [11]) or during the preparation of schochu (O. kitaharae [12]). O. sicerae is found specifically in ciders [13].

Certain particularly efficient LAB strains have been selected and are marketed as malolactic starters [9]. Conversely, certain strains of LAB (including O. oeni) can cause deterioration before, during or after MLF, depending on their genome content and the associated metabolic abilities [14]. Furthermore, the context (type of beverage or even type of wine considered) may also modulate the microbial metabolic activities and thus the risk associated with the presence of a specific strain. The machinery necessary for the biosynthesis of exopolysaccharides (EPSs) is one of the metabolic tools which differentiates the LAB strains. EPS can (i) contribute to bacterial survival in the specific context of the production of fermented drinks, (ii) improve the sensory properties of wines and other fermented drinks or (iii) on the contrary, lead to beverage spoilage $[4,15,16]$.

The aim of this review is to synopsize the current knowledge on the EPSs produced by the LAB of fermented drinks, namely, the nature and location of the EPSs, the genes involved and the active biosynthetic pathways, as well as the consequences of EPS production on the survival of the bacteria and on the quality of the beverages produced. Finally, research perspectives will be examined.

\section{EPSs Produced and Biosynthetic Pathways}

EPSs are extracellular glucidic polymers of variable size (a few tens of monosaccharides to several tens of thousands). They may consist of a single type of monomer (homopolysaccharides) or of several different monomers (heteropolysaccharides), they may be neutral or charged and may or may not contain non-carbohydrate substituents. Finally, they can be linear or branched. Among fermented drinks, the LAB EPSs O. oeni EPSs are the ones that have been the most studied—data on this species will therefore be presented first, and where possible, knowledge will be extended to other species (Table 1).

Table 1. LAB EPSs isolated from fermented beverages.

\begin{tabular}{|c|c|c|c|c|c|c|}
\hline EPS Type & EPS Structure & Species & Niche & $\begin{array}{l}\text { Implicated } \\
\text { Genes }\end{array}$ & $\begin{array}{c}\text { Consequences/Role } \\
\text { of EPS }\end{array}$ & Reference \\
\hline \multirow{8}{*}{ homopolysaccharides } & $\beta$-glucan & Oenococcus oeni & wine, cider & $g t f$ & $\begin{array}{l}\text { ropy character, } \\
\text { stress resistance }\end{array}$ & [17-19] \\
\hline & $\beta$-glucan & $\begin{array}{l}\text { Pediococcus } \\
\text { damnosus }\end{array}$ & cider & $g t f$ & ropy character & {$[17,20-23]$} \\
\hline & $\beta$-glucan & $\begin{array}{l}\text { Pediococcus } \\
\text { parvulus }\end{array}$ & cider, wine & $g t f$ & $\begin{array}{l}\text { ropy character, } \\
\text { stress resistance }\end{array}$ & {$[18,23]$} \\
\hline & $\beta$-glucan & $\begin{array}{l}\text { Pediococcus } \\
\text { ethanolidurans }\end{array}$ & cider & - & ropy character & [24] \\
\hline & $\beta$-glucan & $\begin{array}{c}\text { Pediococcus } \\
\text { claussenii }\end{array}$ & beer & $g t f$ & ropy character & {$[25,26]$} \\
\hline & $\beta$-glucan & $\begin{array}{c}\text { Lactobacillus } \\
\text { brevis }\end{array}$ & beer & $g t f 2$ & $\begin{array}{l}\text { ropy character, } \\
\text { ethanol tolerance, } \\
\text { biofilm formation }\end{array}$ & {$[26,27]$} \\
\hline & $\beta$-glucan & $\begin{array}{l}\text { Lactobacillus } \\
\text { diolivorans }\end{array}$ & cider & $g t f$ & - & [17] \\
\hline & $\beta$-glucan & $\begin{array}{l}\text { Lactobacillus } \\
\text { suebicus }\end{array}$ & cider & $g t f$ & ropy character & {$[28,29]$} \\
\hline
\end{tabular}


Table 1. Cont.

\begin{tabular}{|c|c|c|c|c|c|c|}
\hline EPS Type & EPS Structure & Species & Niche & $\begin{array}{l}\text { Implicated } \\
\text { Genes }\end{array}$ & $\begin{array}{c}\text { Consequences/Role } \\
\text { of EPS }\end{array}$ & Reference \\
\hline & $\beta$-glucan & $\begin{array}{l}\text { Lactobacillus } \\
\text { spp. }\end{array}$ & cider & - & ropy character & [30] \\
\hline & a-glucan & $\begin{array}{c}\text { Leuconostoc } \\
\text { pseudomesen- } \\
\text { teroides, } \\
\text { Weissella confusa }\end{array}$ & beer & $d s r$ & increased viscosity & [31] \\
\hline & dextran & $\begin{array}{l}\text { Leuconostoc } \\
\text { pseudomesen- } \\
\text { teroides }\end{array}$ & $\begin{array}{l}\text { homemade } \\
\text { wine }\end{array}$ & - & - & [32] \\
\hline & $\begin{array}{l}\text { glucan and } \\
\text { fructan }\end{array}$ & $\begin{array}{l}\text { Leuconostoc } \\
\text { mesenteroides }\end{array}$ & $\begin{array}{c}\text { grape must and } \\
\text { wine }\end{array}$ & $\begin{array}{l}\text { Glucosyltransferase } \\
\text { gene }\end{array}$ & $\begin{array}{l}\text { more or less mucoid } \\
\text { strains }\end{array}$ & [33] \\
\hline & dextran and levan & Oenococcus oeni & wine & $d s r O$ and $l e v O$ & $\begin{array}{l}\text { lyoprotective ability } \\
\text { to freeze-drying } \\
\text { process }\end{array}$ & {$[15,34,35]$} \\
\hline \multirow{4}{*}{ heteropolysaccharides } & $\begin{array}{l}\text { glucose, galactose, } \\
\text { rhamnose }\end{array}$ & Oenococcus oeni & wine & eps cluster & $\begin{array}{c}\text { aromatic } \\
\text { complexity, biofilm } \\
\text { formation, capsule, } \\
\text { lyoprotective ability } \\
\text { to freeze-drying }\end{array}$ & {$[15,34-36]$} \\
\hline & $\begin{array}{l}\text { glucose, galactose, } \\
\text { galactofuranose } \\
\text { glucose, galactose }\end{array}$ & $\begin{array}{l}\text { Lactobacillus } \\
\text { suebicus }\end{array}$ & cider & $g t f$ & ropy character & {$[28,29]$} \\
\hline & $\begin{array}{l}\text { N-acetyl- } \\
\text { glucosamine, } \\
\text { phosphate }\end{array}$ & $\begin{array}{l}\text { Lactobacillus } \\
\text { suebicus }\end{array}$ & cider & eps cluster & ropy character & [37] \\
\hline & $\begin{array}{l}\text { glucose, galactose, } \\
\text { glucosamine }\end{array}$ & $\begin{array}{l}\text { Pediococcus } \\
\text { ethanolidurans }\end{array}$ & cider & - & ropy character & [24] \\
\hline
\end{tabular}

\subsection{EPSs Produced by Wine and Cider LAB in Brief}

The $\beta-1,3 \beta-1,2$ glucan was the first EPS produced by wine or cider LAB to be identified [21]. It comprises a backbone made of $\beta-1,3$ linked glucoses and branches made of a single $\beta-1,2$ linked glucose attached to each of the two or three residues of the main chain. This polymer will be referred to as " $\beta$-glucan" throughout this review. Its accumulation in beverages induces an increase in viscosity and even a ropy character: the wine, beer or cider can harbor an oily texture, even when $\beta$-glucan concentrations are as low as $12 \mathrm{mg} / \mathrm{L}$ [38]. Many bacterial species are able to produce this specific glucan: O. oeni, Lactobacillus suebicus, Lactobacillus diolivorans, Pediococcus parvulus, Pediococcus damnosus, Lactobacillus collinoides, Lactobacillus brevis, Lactobacillus rossiae, Lactobacillus parabuchneri and Levilactobacillus brevis $[17,18,20,23,26-28,30,37,39,40]$. Additionally, heteropolysaccharides, dextrans and fructans are also produced by $O$. oeni and some other species [38].

Many wine or cider bacteria have been shown to produce several types of polymers simultaneously. For example, certain strains of $O$. oeni isolated from wine or cider produce both dextran ( $\alpha-1,6-\alpha-1,3$ glucan), levan ( $\beta-2,6$ fructan), $\beta$-glucan and heteropolysaccharides composed of galactose, glucose and rhamnose [35]. Pediococcus ethanolidurans isolated from Basque cider also produces both ropy $\beta$-glucan and a heteropolysaccharide composed of glucose, galactose, glucosamine and glycerol-3-phosphate [24].

However, depending on the conditions, one of the polymers formed is much more abundant than the others and explains the dominant phenotype of the strain: capsulated, mucous, ropy or sticky $[35,41]$. The production could be modulated by the presence of numerous phenolic compounds in these beverages [42]. Furthermore, in wine or grape juice, the concentrations of the EPS produced are often hardly noticeable due to the presence of numerous other polysaccharides liberated from the grapes and yeasts [43,44].

\subsection{EPS Localization}

EPS can be classified into three major groups, according to their exact external location [45]: 
- WPS or wall polysaccharides, attached to the cell, covalently or not, but without forming a capsule.

- CPS (or capsular polysaccharides), most of the time linked to peptidoglycan, forming either a thick and cohesive (capsule) or a thin and cohesive (film) outer layer.

- Exocellular polysaccharides (or true EPSs), released into the environment surrounding the cell during planktonic growth. This kind of true EPS can also form a slime or a polymeric matrix during growth on solid media or biofilm formation.

The distinction between these polysaccharides is sometimes controversial. The capsules are observable in negative staining in classical microscopy, but some polymers can form a dense layer that is visible in electron microscopy but not thick enough to be visible in negative staining [46,47]. In addition, CPS can be released depending on the growing conditions or due to unstable cell binding and can be mistaken for EPSs. Conversely, certain EPSs can be found linked to the cell and to the peptidoglycan, even non-covalently [46].

For instance, most $O$. oeni strains studied are encapsulated by a heteropolysaccharidic layer and this kind of "capsule" seems to be present regardless of the culture conditions. However, some of these CPSs are released into the surrounding medium at the end of the stationary phase [35] or during growth on solid media [27]. On the other hand, the capsular $\beta$-glucan of $P$. parvulus 2.6, a ropy strain isolated from cider, can be released from the cell "capsule" into the medium by means of simple cell washes [48].

\subsection{Biosynthetic Pathways}

The EPS biosynthetic pathways involving sugar nucleotides have been extensively studied in milk LAB (Streptococcus thermophilus, Lactobacillus rhamnosus and Lactococcus lactis) and in pathogenic streptococci (Streptococcus pneumonia and Streptococcus agalactiae) [49-54]. Dextran and levan synthesis have been mainly studied in Lc. mesenteroides [55].

Similar pathways were found to be active in LAB of wine and fermented beverages. Actually, in these specific bacteria, three types of cellular machinery dedicated to the biosynthesis of EPSs have been described to date (Figure 1): (i) extracellular transglycosidases called glycansucrases, which use sucrose as a substrate and catalyze the synthesis of homopolysaccharides ( $\alpha$-glucans, $\beta$-fructans); (ii) isolated synthases that use nucleotide sugars as substrates and which alone catalyze the polymerization and export of homopolysaccharides; and (iii) complex systems involving nucleotide sugars as substrates and many enzymes that achieve the synthesis and export of complex heteropolysaccharides together [38].

(i) Transglycosidases, which specifically use sucrose as a substrate (or glycansucrases), are classified into the CAZy GH-13, 68 and 70 families (www.cazy.org (accessed on 14 September 2021)) [56]. They catalyze the synthesis of homopolysaccharides made up of glucose or fructose, according to the following simplified reactions:

$$
\begin{gathered}
\text { n sucrose } \rightarrow \text { (fructose) } \mathrm{n}+\mathrm{n} \text { glucose (fructansucrase) } \\
\mathrm{n} \text { sucrose } \rightarrow \text { (glucose) } \mathrm{n}+\mathrm{n} \text { fructose (glucansucrase) }
\end{gathered}
$$

These enzymes are exocellular (Figure 1). They catalyze the synthesis of polysaccharides via a succession of donor-acceptor type reactions (a processive mechanism [57]). They are produced by certain strains of different species found in fermented beverages $(O$. oeni, O. kitaharae, Lc. mesenteroides, Lc. pseudomesenteroides) $[32,33,35,41,58]$. The structure of the polymer produced varies depending on the producing enzyme, both in terms of the type of osidic bonds formed $(\alpha-1,6$ and $\alpha-1,3$ in varying proportions for glucans and mainly $\beta-2,6$ for fructans), and in terms of degree of polymerization. Interestingly, the dextran produced by the enzyme DsrOK from O. kitaharae is one of the largest ever studied [58]. The enzyme also displays a very high catalytic efficacy, whereas the enzyme DsrO of O. oeni is poorly efficient and quite unstable [34,58]. 


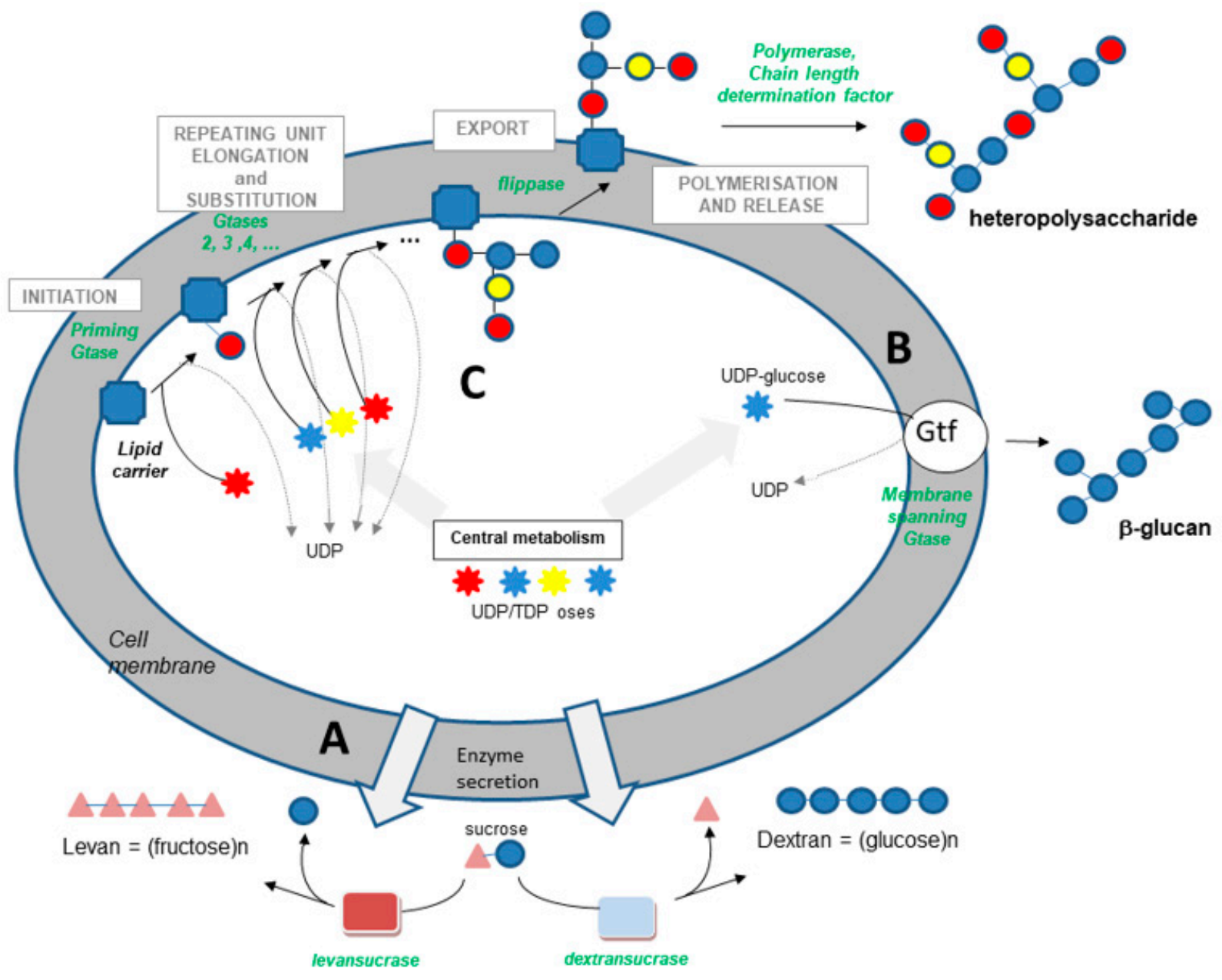

Figure 1. Overview of the EPS biosynthetic pathways active in O. oeni and other LAB from fermented beverages. From top to bottom and right to left: (A) Dextran ( $\alpha$-glucan) and levan ( $\beta$-fructan) synthesis from sucrose by external glycansucrases such as dextransucrase or levansucrase. (B) $\beta$-glucan synthesis involving UDP-glucose and the membrane spanning glycosyltransferase Gtf. (C) Heteropolysaccharide synthesis: the repeating unit is built via the involvement of priming glycosyltransferase and several other glycosyltransferases, a lipid carrier and activated substrates (UDP-oses). Then, the complete repeating unit is externalized by a flippase and is polymerized outside the cell before the release of the polymer. Gtase, glycosyltransferase.

(ii) The synthase pathway involves a single membrane-spanning enzyme, which alone carries out the initiation of synthesis, the elongation of the polymer (processive enzyme) and its export through the membrane (Figure 1). The $\beta$-glucan causing wine or cider ropiness is produced by an enzyme of this type, called Gtf. The role of Gtf in the synthesis of P. parvulus and O. oeni $\beta$-glucan was demonstrated in 2006 and $2008[17,18]$. Gtf is $32 \%$ identical to Tts, a synthase found in S. pneumoniae type 37, which produces a $\beta$-glucan with structure close to that produced by wine, beer and cider strains. This pneumococcal glucan is immunogenic in humans, as in mice, and was shown to be responsible for pneumococcal strain virulence [59].

(iii) The third pathway is the most complex (Figure 1). This pathway is sometimes called the Wzy-dependent pathway, based on the name given to the polymerase in E. coli [60]. This pathway has been perfectly characterized in Gram-negative bacteria and partially in Gram-positive bacteria [49-52,60]. The first step is the synthesis of a repeating oligosaccharidic unit through the transfer of monomers to a lipid transporter on the inner face of the cell membrane (Figure 1). This synthesis, carried out by a series of non-processive glycosyltransferases, is followed by the export of the repeating unit by a flippase (Wzx) and by the assembly of the exported repeating units by a polymerase 
attached to the external face of the cell membrane (Wzy). Regulating enzymes and factors modulate the chain length and the polymer release. The glycosyltransferase which initiates the synthesis of the repeat unit by transferring the first monomer to the lipid transporter is called the "priming glycosyltransferase". Several priming glycosyltransferases are found in O. oeni and complement each other [61], ensuring EPS formation even in cases in which mutations inactivate one of the enzymes.

The distinction between biosynthetic pathways using a transglycosidase and sucrose as a precursor or glycosyltransferase(s) and sugar nucleotides is very important from a physiological point of view-the biosynthetic pathways involving sugar nucleotides are very "expensive" for the bacteria from an energetic point of view. They compete for nucleotide sugars with the cell-wall synthetic pathways, which limits the production levels of liberated polymers to a few hundred $\mathrm{mg} / \mathrm{L}$, whereas the production levels can rise to a few tens of grams per liter, in the case of glucansucrase using sucrose [35,41,44,62]. The O. oeni strains equipped with active glucansucrase or fructansucrases release from 0.2 to $8 \mathrm{~g} / \mathrm{L}$ of polymers depending on the strains and growing conditions. Sucrose has to be added to the growth media [34,35]. In the presence of high sucrose concentrations, Lc. mesenteroides isolated from Spanish wines can produce $500 \mathrm{mg} / \mathrm{L}$ of dextran [33].

The Wzy-dependent pathway leads to the release of at most $250 \mathrm{mg} / \mathrm{L}$ of heteropolysaccharide in O. oeni and about $50 \mathrm{mg} / \mathrm{L}$ in $P$. ethanolidurans $[24,35,44]$. Furthermore, depending on the bacterial strain and the growth conditions, the concentration of $\beta$-glucan can vary between 10 and $250 \mathrm{mg} / \mathrm{L}[18,19,44]$.

\subsection{Genes Associated with EPS Synthesis}

Glycansucrases and autonomous synthase, which are enzymes capable of catalyzing the synthesis of polymers on their own, are generally encoded by isolated genes, whereas Wzy-dependant pathways are generally encoded by genes in large clusters or operons. The eps genes can be chromosomal or plasmidic. In wine and cider LAB, some of these genes seem extremely mobile, in particular the gtf gene, associated with the synthesis of the $\beta$-glucan causing wine or cider ropiness. In fact, it is carried by at least four different plasmids within the genus Pediococcus $[17,23,24,63]$, and it is chromosomic (but inserted in a phage remnant or even in a prophage) in O. oeni [18,35]. Despite the high number of genetic locations, the gene is more than $95 \%$ conserved between the bacterial species capable of producing the ropy $\beta$-glucan: Lb. suebicus, Lb. diolivorans, P. parvulus, P. damnosus, Lb. collinoides and O. oeni $[17,18,23,28,30,37,39,40]$. This suggests either a recent transfer between the bacteria or a high-level conserved amino acid sequence requirement for maintaining the activity.

Dextransucrase genes are generally chromosomic and highly conserved in $O$. oeni, even though the main habitat of the species, wine, does not contain any sucrose. Truncated forms are sometimes found but most of the time the $d s r O$ gene is not truncated [35]. This nearly ubiquitous presence of a very large dextransucrase gene ( $>3000 \mathrm{bp}$ ) suggests that dextransucrase activity is important for the survival of the species, but this may be in a context other than wine. Other Oenococcus species also display dextransucrase genes, except in O. kitaharae these have not yet been characterized [58].

In $\mathrm{LAB}$, the genes encoding the enzymes involved in the Wzy-dependent pathway are organized in clusters or operons, in which regulatory genes or genes for the synthesis of precursors are often found $[35,64,65]$. These clusters still exhibit a high density of coding zones and are chromosomic in the fermented-drink LAB strains studied to date. In O. oeni the eps gene cluster organization is often unidirectional (Figure 2). The $5^{\prime}$ region is the most conserved one and it displays regulatory genes, the priming glycosyltransferase gene, then the genes encoding the other glycosyltransferases, together with genes involved in precursor biosynthesis, followed by wzy and wzx. Dimopoulou et al. found 14 distinct complete eps clusters out of 50 O. oeni genomes studied [35]. Recombination events are certainly at the origin of the final diversity observed. These recombination events may lean on the conserved $5^{\prime}$ region of the eps gene cluster and on the $3^{\prime}$ end, on the gene recP 
(Figure 2). The size of the chromosome region concerned in the recombination process can be as high as $50 \mathrm{~kb}$. Such a diversity of eps gene clusters is often described as a component of adaptation to host defense mechanisms in pathogenic bacteria [66-68]. Actually, more than 88 wzy-dependent gene clusters, causing as many serotypes, have been described in S. pneumoniae [65].
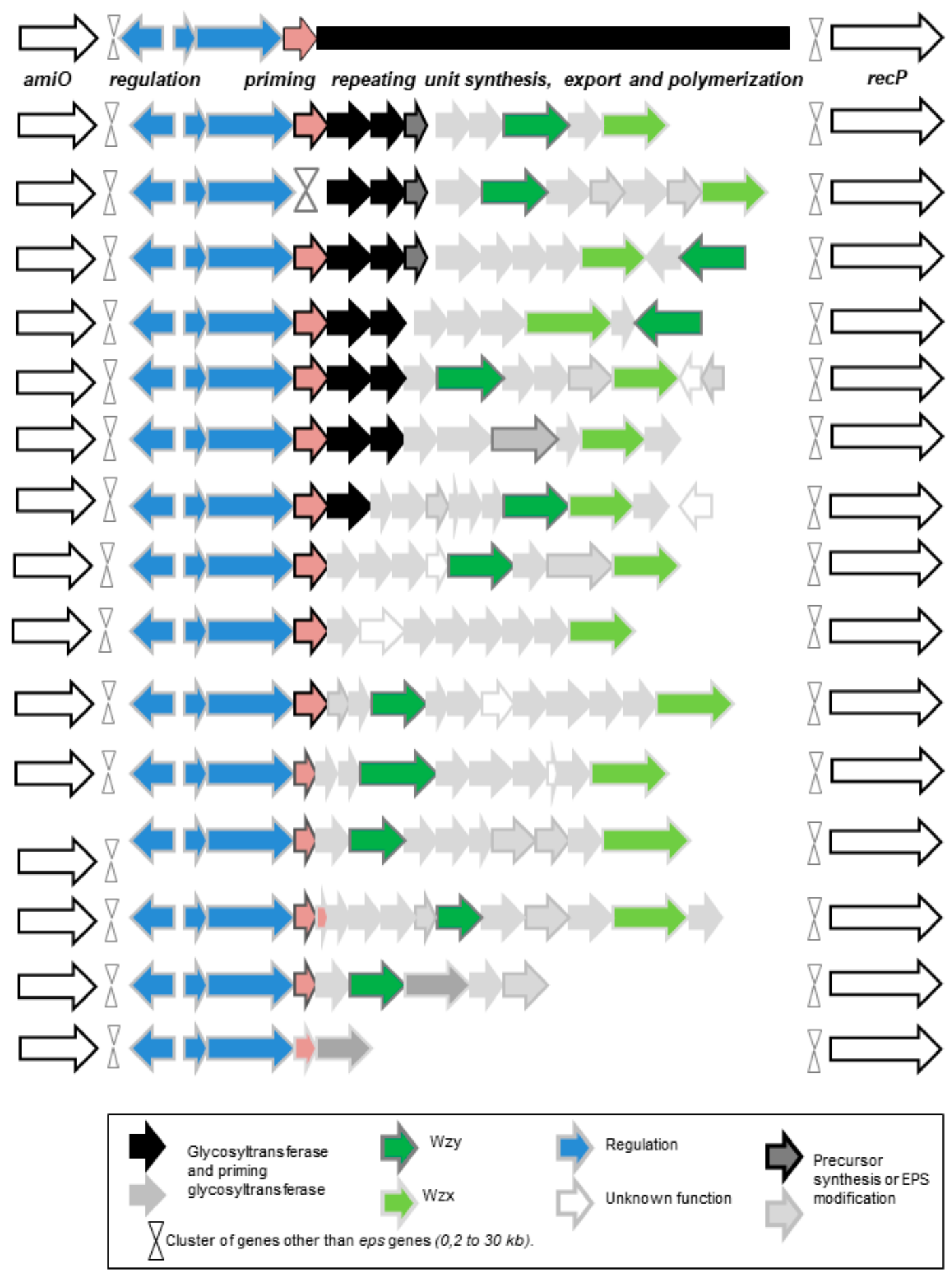

Figure 2. Consensus organization of eps gene cluster 2 in O. oeni (adapted from Dimopoulou et al. [35]).

To sum up, in the O. oeni chromosome, regardless of the strain considered, there is at least one gene dedicated to EPS synthesis which encodes a functional pathway, and very often several genes encode several active pathways [35]. However, the selective advantage 
of such a high diversity of eps genes and clusters for O. oeni, a non-pathogenic bacterial species, remains unclear. This point will be further discussed in the following paragraphs.

This eps gene cluster is present in more than $85 \%$ of the O. oeni strains studied and it is associated with capsular polysaccharide synthesis. Only the last one presented in the bottom of this figure encodes an inactive pathway (no CPS produced; the gene transcription was not examined). The cluster is highly variable, especially in its $3^{\prime}$ end, whereas the $5^{\prime}$ end sequence is more conserved. The genes $w z x$ and $w z y$ are the most divergent ones and appear to be specific to each complete cluster. Several recombination events upstream and downstream of the eps locus may have led to the diversity observed. These events may lean on recP or the cluster of genes inserted between recP and the $3^{\prime}$ end of the eps gene cluster, or even on the eps gene cluster itself. In parallel, recombination events may have occurred upstream of eps gene cluster 2, between the genes of $a m i O$ and wze or wzd.

\section{What Could Be the Consequences for the Winemaker or the Wine Lover?}

The exact role of polysaccharides in bacterial physiology is not perfectly understood. Nevertheless, the fact that the majority of the wine microorganisms have the ability to produce several EPS structures independently of the genus, species or strain could indicate the importance of these polymers for the survival of the individuals or for maintaining the species. The production of fermented beverages from fruits is a seasonal activity. Microorganisms must therefore survive not only during the beverage production process but also, once the beverages are produced, in cellars or factories and/or in orchards and vineyards for almost a year. LAB may therefore be able to survive in the gastrointestinal tract of insects and birds that gravitate to production areas and/or on production equipment or on trees, plants and soils, which would promote (1) their survival between seasons and (2) their natural spread or their human-driven spread (wine trade, exchange of winemaking materials, Figure 3).
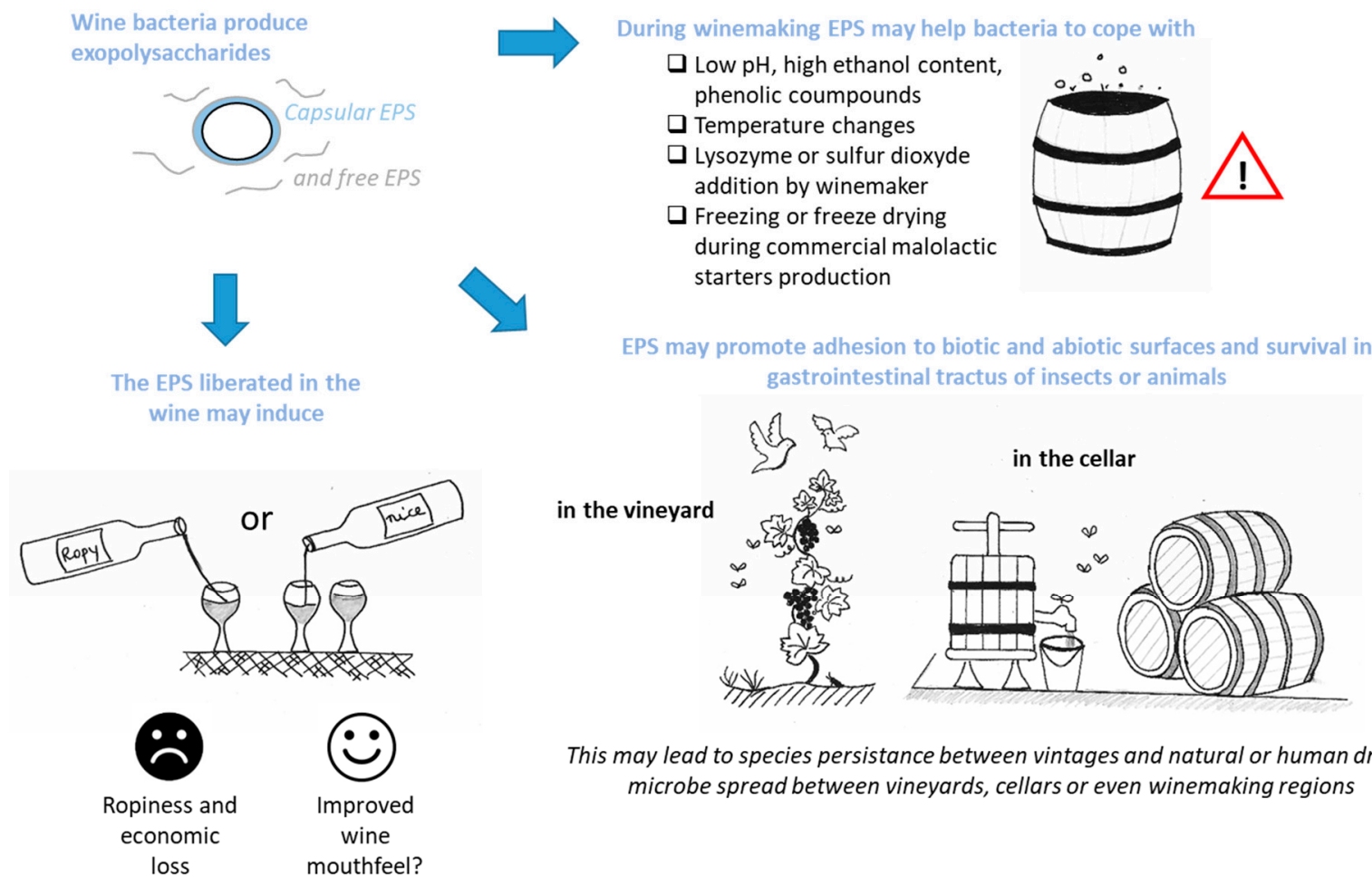

This may lead to species persistance between vintages and natural or human driver microbe spread between vineyards, cellars or even winemaking regions

Figure 3. Possible incidence of bacterial polysaccharides in the specific context of winemaking. 


\subsection{EPSs for Bacteria Survival in Harsh Winemaking Conditions}

The presence of an extracellular polymeric matrix could be implicated in the protection of the cell in various situations including wine or cider elaboration [69,70]. Indeed, many bacteria enhance EPS synthesis as a response to carbon dioxide release by yeasts during $\mathrm{AF}[71,72]$ or in the case of various stresses such as low $\mathrm{pH}$ or high ethanol or phenolic compound concentrations [23,34]. For example, $\beta$-glucan seems to increase the resistance of the producing bacteria to acidic $\mathrm{pH}[18,27,48]$. In France, the prevalence of ropy O. oeni strains is particularly high in regions producing naturally more acidic wines (Bourgogne or Champagne) $[18,73,74]$. The increase in viscosity induced by $\beta$-glucan may slow down the diffusion of abiotic compounds, such as phenolic compounds, sulfites, and ethanol, and protect the bacteria. By constituting a protective layer, $\beta$-glucan is also involved in the resistance of LAB to lysozyme treatment [75]. LAB CPSs and dextrans can also offer protection during the freeze-drying step in malolactic starter production $[34,76]$. On the other hand, the phage resistance associated with EPSs is controversial and EPSs could, depending on the case, serve as a target for attachment and recognition or, on the contrary, as a masking element for these targets $[77,78]$.

\subsection{EPSs, Biotic Interactions and Species Survival}

Beta-glucan was shown to promote the adhesion of bacteria to intestinal cells and to play a role in cross feeding in the intestinal tract, and this may promote microbial survival in the intestinal tracts of various animal and insects, and hence in bacterial dissemination and the colonization of new ecological niches [48,79-81]. In the same way, the high diversity of capsular heteropolysaccharides produced by O. oeni may be involved in bacterial survival in a biotic context, through interactions or adhesion to epithelial receptors in the gastrointestinal tracts of insects or animals. The capsule may also constitute a protection against host defense mechanisms and promote host colonization, as shown for many pathogenic Gram-positive and Gram-negative bacteria [66,82,83]. Nevertheless, further work will be necessary to identify the hosts in which wine LAB are accommodated between two vintages, if any.

O. oeni glucansucrase genes are highly conserved, despite the fact that the encoded enzymes use a substrate, sucrose, that is rarely found in wine but is present in grapes. The production of dextran on grapes may assist the attachment of the bacteria to fruits or to vine woods. It may also promote their survival in the soil, as suggested a long time ago for Lc. mesenteroides [84]. Furthermore, EPS-producing LAB adheres better to S. cerevisiae cells, which efficiently consume lactic acid and consequently decrease the acidity of the medium, subsequently promoting bacterial growth $[85,86]$.

\subsection{EPSs and Bacterial Colonization of the Production Cellar}

EPSs may help the wine microorganism to invade during all the winemaking steps through promoting adhesion onto abiotic surfaces, i.e., stainless steel, plastic and glass surfaces, as well as the wood of oak barrels. Undoubtedly, the presence of EPSs modulates the physicochemical characteristics of the LAB cell surface [87]. In some cases, EPSs were shown to be implicated in the adhesion process [88,89]. Adhered cells can, in the second phase, evolve into biofilms. Biofilms are complex structures composed mainly of an extracellular matrix, genetic material and microorganisms. Depending on the case, abundant EPSs can increase or decrease the adhesion capacity and biofilm formation [90].

The same could be assumed for the EPSs produced by wine LAB, i.e., dextran, $\beta$ glucan and heteropolysaccharides. EPSs may be important for O. oeni biofilm settlement as the genes implicated in heteropolysaccharide and homopolysaccharide production are overexpressed under stressed biofilm conditions [36]. More recently, it has been demonstrated through FT-IR spectra analysis that the metabolic fingerprint of the attached cells was significantly different from that of the planktonic ones, and the spectral zone associated with polysaccharides was discriminative. This suggests the importance of EPSs in biofilm formation on stainless steel surfaces [91]. The $\beta$-glucan produced by O. oeni 
or recombinant L. lactis expressing $g t f$ may be involved in the last steps of adhesion and biofilm consolidation, rather than primary adhesion [18]. Regarding O. oeni dextran, the research carried out so far has not made it possible to determine whether it promotes or whether it prevents attachment to abiotic surfaces. This may depend on the strain and the context in which the cells develop. Nácher-Vázquez et al. [92] compared the biofilm formation and aggregation ability of two different bacterial species, Lc. mesenteroides and Lb. sakei, both of which are great producers of dextrans. Interestingly, only Lb. sakei formed a biofilm on the tested abiotic surfaces, whereas dextran exerted an antiadhesive effect in the case of the strain of Lc. mesenteroides. Thus, the authors proposed that the role of dextran was involved in the aggregation process and biofilm consolidation, rather than in the primary adhesion process, which is rather linked to the surface proteins of the bacteria. Dextran, which is a neutral and weakly adhesive polymer, may aid in the attachment process by masking repulsion molecules. By contrast, it could prevent adhesion by masking motifs essential for primary adhesion $[93,94]$.

The most important point is that biofilms are a strategy used to overcome stressful conditions [95]. O. oeni cells attached to stainless steel and oak wood surfaces can perform malolactic fermentation and display higher tolerance to wine stress than planktonic ones [36]. In the same way, the biofilm cells of $L b$. plantarum expressed higher resistance to acetic acid and low $\mathrm{pH}$ values than the planktonic cells [69].

\subsection{Beverage Spoilage and Possible Treatments}

Some of the EPSs from wine bacteria are implicated in a specific form of wine spoilage, the disease known as "ropiness". The polymer produced increases the wine's viscosity and sometimes induces an oily sensation [96]. This ropy character may be perceived with the naked eye and can occur in stainless-steel tanks, in barrels and even in the bottle. If the alteration remains at bottle opening, the consumer who discovers the defect sometimes definitively turns away from the wine from the area concerned and this may provoke great losses for the wine industry (Figure 3).

For the moment, the only molecule clearly implicated in ropiness is the $\beta$-glucan described in the previous paragraph, but other molecules could be implicated in other bacteria [23]. Interestingly, wine LAB displaying the ropy phenotype in laboratory media may be isolated from non-ropy wines [44]. This observation indicates that the effect of EPSs on wine depends on many factors and the presence of a "ropy" strain is not sufficient to provoke wine spoilage. In the first place, spoilage is not correlated with EPS quantity but mainly with EPS structure, as just $12 \mathrm{mg} / \mathrm{L}$ of $\beta$-glucan may provoke ropiness, whereas some $\mathrm{g} / \mathrm{L}$ of dextran do not induce such a viscosity change. In addition, the role of the wine or cider matrix is essential as interactions of the polymer with the matrix may enhance the viscosity. Interestingly the Lactobacillus and Pediococcus strains producing $\beta$-glucan are also implicated in beer and cider spoilage $[20,26,39,97]$. P. parvulus is the species that is most often involved in the ropiness of wine and ciders, as it develops after fermentation processes in the late stages of winemaking, even after bottling. O. oeni ropy strains are quite frequent but, as they develop in the early stages of winemaking, when wine supervision is easier, they are less dangerous for the final quality of the wine (Table 1). Indeed, the vigorous stirring of the wine is enough to make the ropy character disappear and a close supervision of the microbial flora during the following stages of winemaking may guarantee that the viscosity remains low. The well-developed qPCR protocols for the detection of ropy strains, through the detection of $g t f$ genes, constitute an interesting tool for wine supervision, early reaction and curative or preventive treatments $[17,19,98]$. However, LAB spoilage species could be resistant to $\mathrm{SO}_{2}$ treatment, as well as to lysozyme [18,75]. Nevertheless, the ropy strains could be remedied via the simultaneous enzymatic action of $\beta$-glucanase and lysozyme, as recommended by Coulon et al. [75]. A combined treatment of low concentrations of enterocin AS-48, along with high-intensity pulsed-electric field (HIPEF) treatment, was also shown to inactivate exopolysaccharide-producing LAB strains 
in apple juice, but these methods need to be investigated more and are not currently allowed [99-101].

\subsection{Bacterial EPSs and Wine Sensorial Properties}

For years, bacterial polysaccharides were considered to have no impact on wine, except for $\beta$-glucan accumulation and ropiness (see previous paragraph). However, bacterial polysaccharides accumulate in wine during MLF and later even when no viscosity increase is noticeable [35,43]. These biopolymers could directly or indirectly have an impact on the wine's sensory profile, as previously shown for yeast mannoproteins (MPs) [102-104]. In fact, MP enrichment of wines have been proven to modify wine astringency and sucrosity $[105,106]$. MPs have also been mentioned to play an important role in tartrate salt crystallization, although the MP concentration needs to be adjusted depending on the wine considered [107-109]. Additionally, recent studies have shown that MPs can interact with all anthocyanin families and modulate the bioaccessibility of polyphenolic compounds during digestion in the gastrointestinal tract [110]. In addition, pectin, a heteropolysaccharide mainly composed of partially methylated galacturonic acid, can inhibit proteins and tannin precipitation [111]. These interactions also depend on the hydrophobicity and molecular weight of the phenolic compounds [112]. In the same way, the EPSs liberated by LAB could interfere with tannins and salivary proteins and thus reduce the sense of astringency. This could be the case with O. oeni dextrans. Indeed, small commercial dextrans ( $>5000 \mathrm{da}$ ) were shown to increase the mouthfeel sensation and to decrease wine astringency (Dimopoulou et al., unpublished).

Even if polysaccharides are not volatile molecules, they may indirectly contribute to aroma perception. Olfactory perception is a complicated phenomenon in which molecular interactions play a crucial role. Dimopoulou et al. [34] suggested for the first time that the bacterial EPSs produced in wine could contribute to aromatic complexity and fruity aromas. These may affect the release of esters and alcohols from the liquid phase, affecting their concentration in the head space [113]. Indeed, the wine matrix plays an essential role in the in vivo aroma release [114]. When dextrans from Lc. mesenteroides were added to wine model medium, isoamyl acetate and ethyl hexanoate esters were salted out in the vapor phase as the presence of polysaccharides decreased their solubility [115]. Bastard et al. [36] also suggest an interaction between the biofilm formed on the oak surface and wine, contributing to the expression of trans-whisky lactone complexity.

\section{Conclusions}

The ability of LAB to produce EPSs in wine and other fermented beverages has been known for a long time, but mainly in the context of ropy $\beta$-glucan accumulation and wine spoilage. Great genotypic and phenotypic diversity within LAB EPS producers, especially $O$. oeni, has been more recently elucidated. The more the research advances, the more the complexity of EPS biosynthesis in fermented beverages is unraveled, revealing the multiple biosynthetic pathways and the associated phenotypic diversity. The effects of the EPSs produced on bacterial survival and dissemination, as well as on wine quality, are complex and trigger many fascinating research perspectives for the future. An important question is whether the EPSs produced by LAB of fermented beverages ultimately have a positive or negative effect. No one-word answer to this question yet exists, and this will certainly require many years of work.

Author Contributions: Conceptualization, M.D. and M.D.-L.; methodology, M.D. and M.D.-L. All authors have read and agreed to the published version of the manuscript.

Funding: This research received no external funding.

Institutional Review Board Statement: Not applicable.

Informed Consent Statement: Not applicable.

Conflicts of Interest: The authors declare no conflict of interest. 


\section{References}

1. König, H.; Berkelmann-Löhnertz, B. Lactic Acid Bacteria. In Biology of Microorganisms on Grapes, in Must and in Wine; König, H., Unden, G., Fröhlich, J., Eds.; Springer: Cham, Switzerland, 2017; pp. 3-41. ISBN 978-3-319-60021-5.

2. König, H.; Berkelmann-Löhnertz, B. Maintenance of Wine-Associated Microorganisms. In Biology of Microorganisms on Grapes, in Must and in Wine; König, H., Unden, G., Fröhlich, J., Eds.; Springer: Cham, Switzerland, 2017; pp. 549-571. ISBN 978-3-319-60020-8.

3. Davis, C.R.; Wibowo, D.; Eschenbruch, R.; Lee, T.H.; Fleet, G.H. Practical Implications of Malolactic Fermentation: A Review. Am. J. Enol. Vitic. 1985, 36, 290-301.

4. Lonvaud-Funel, A. Lactic Acid Bacteria in the Quality Improvement and Depreciation of Wine. Antonie Van Leeuwenhoek 1999, 76, 317-331. [CrossRef]

5. Versari, A.; Parpinello, G.P.; Cattaneo, M. Leuconostoc oenos and Malolactic Fermentation in Wine: A Review. J. Ind. Microbiol. Biotechnol. 1999, 23, 447-455. [CrossRef]

6. Sumby, K.M.; Grbin, P.R.; Jiranek, V. Microbial Modulation of Aromatic Esters in Wine: Current Knowledge and Future Prospects. Food Chem. 2010, 121, 1-16. [CrossRef]

7. Sánchez, A.; Rodríguez, R.; Coton, M.; Coton, E.; Herrero, M.; García, L.A.; Díaz, M. Population Dynamics of Lactic Acid Bacteria during Spontaneous Malolactic Fermentation in Industrial Cider. Food Res. Int. 2010, 43, 2101-2107. [CrossRef]

8. Sánchez, A.; Coton, M.; Coton, E.; Herrero, M.; García, L.A.; Díaz, M. Prevalent Lactic Acid Bacteria in Cider Cellars and Efficiency of Oenococcus oeni Strains. Food Microbiol. 2012, 32, 32-37. [CrossRef]

9. Bartowsky, E.J. Oenococcus oeni and Malolactic Fermentation-Moving into the Molecular Arena. Aust. J. Grape Wine Res. 2005, 11, 174-187. [CrossRef]

10. Lorentzen, M.P.G.; Lucas, P.M. Distribution of Oenococcus oeni Populations in Natural Habitats. Appl. Microbiol. Biotechnol. 2019, 103, 2937-2945. [CrossRef]

11. Badotti, F.; Moreira, A.P.B.; Tonon, L.A.C.; de Lucena, B.T.L.; Fátima de Cássia, O.G.; Kruger, R.; Thompson, C.C.; de Morais, M.A.; Rosa, C.A.; Thompson, F.L. Oenococcus alcoholitolerans Sp. Nov., a Lactic Acid Bacteria Isolated from Cachaça and Ethanol Fermentation Processes. Antonie Van Leeuwenhoek 2014, 106, 1259-1267. [CrossRef]

12. Endo, A.; Okada, S. Oenococcus kitaharae Sp. Nov., a Non-Acidophilic and Non-Malolactic-Fermenting Oenococcus Isolated from a Composting Distilled Shochu Residue. Int. J. Syst. Evol. Microbiol. 2006, 56, 2345-2348. [CrossRef]

13. Cousin, F.J.; Le Guellec, R.; Schlusselhuber, M.; Dalmasso, M.; Laplace, J.-M.; Cretenet, M. Microorganisms in Fermented Apple Beverages: Current Knowledge and Future Directions. Microorganisms 2017, 5, 39. [CrossRef]

14. Bartowsky, E.J. Oenococcus oeni and the Genomic Era. FEMS Microbiol. Rev. 2017, 41, S84-S94. [CrossRef]

15. Dimopoulou, M.; Bardeau, T.; Ramonet, P.-Y.; Miot-Certier, C.; Claisse, O.; Doco, T.; Petrel, M.; Lucas, P.; Dols-Lafargue, M. Exopolysaccharides Produced by Oenococcus oeni: From Genomic and Phenotypic Analysis to Technological Valorization. Food Microbiol. 2016, 53, 10-17. [CrossRef]

16. Dols Lafargue, M. Polysaccharide Production by Wine Lactic Acid Bacteria: Negative Trait or Potential Advantage? A Review. Appl. Microbiol. 2018, 4, 1-8. [CrossRef]

17. Werning, M.L.; Ibarburu, I.; As, M.T.D.; Irastorza, A.; Navas, J.S.; Pez, P.L. Pediococcus Parvulus Gtf Gene Encoding the GTF Glycosyltransferase and Its Application for Specific PCR Detection of $\beta$-D-glucan-producing Bacteria in Foods and Beverages. J. Food Prot. 2006, 69, 161-169. [CrossRef]

18. Dols-Lafargue, M.; Lee, H.Y.; Le Marrec, C.; Heyraud, A.; Chambat, G.; Lonvaud-Funel, A. Characterization of Gtf, a Glucosyltransferase Gene in the Genomes of Pediococcus parvulus and Oenococcus oeni, Two Bacterial Species Commonly Found in Wine. Appl. Environ. Microbiol. 2008, 74, 4079-4090. [CrossRef] [PubMed]

19. Ibarburu, I.; Aznar, R.; Elizaquível, P.; García-Quintáns, N.; López, P.; Munduate, A.; Irastorza, A.; Dueñas, M.T. A Real-Time PCR Assay for Detection and Quantification of 2-Branched (1,3)-Beta-D-Glucan Producing Lactic Acid Bacteria in Cider. Int. J. Food Microbiol. 2010, 143, 26-31. [CrossRef]

20. Duenas, M.; Irastorza, A.; Fernandez, K.; Bilbao, A. Heterofermentative Lactobacilli Causing Ropiness in Basque Country Ciders. J. Food Prot. 1995, 58, 76-80. [CrossRef]

21. Llaubères, R.M.; Richard, B.; Lonvaud, A.; Dubourdieu, D.; Fournet, B. Structure of an Exocellular Beta-D-Glucan from Pediococcus sp., a Wine Lactic Bacteria. Carbohydr. Res. 1990, 203, 103-107. [CrossRef]

22. Gindreau, E.; Walling, E.; Lonvaud-Funel, A. Direct Polymerase Chain Reaction Detection of Ropy Pediococcus damnosus Strains in Wine. J. Appl. Microbiol. 2001, 90, 535-542. [CrossRef]

23. Walling, E.; Gindreau, E.; Lonvaud-Funel, A. A Putative Glucan Synthase Gene Dps Detected in Exopolysaccharide-Producing Pediococcus damnosus and Oenococcus oeni Strains Isolated from Wine and Cider. Int. J. Food Microbiol. 2005, 98, 53-62. [CrossRef] [PubMed]

24. Llamas-Arriba, M.G.; Pérez-Ramos, A.; Puertas, A.I.; López, P.; Dueñas, M.T.; Prieto, A. Characterization of Pediococcus ethanolidurans CUPV141: A $\beta$-D-Glucan- and Heteropolysaccharide-Producing Bacterium. Front. Microbiol. 2018, 9, 2041. [CrossRef]

25. Pittet, V.; Morrow, K.; Ziola, B. Ethanol Tolerance of Lactic Acid Bacteria, Including Relevance of the Exopolysaccharide Gene Gtf. J. Am. Soc. Brew. Chem. 2011, 69, 57-61. [CrossRef] 
26. Fraunhofer, M.E.; Geissler, A.J.; Wefers, D.; Bunzel, M.; Jakob, F.; Vogel, R.F. Characterization of $\beta$-Glucan Formation by Lactobacillus brevis TMW 1.2112 Isolated from Slimy Spoiled Beer. Int. J. Biol. Macromol. 2018, 107, 874-881. [CrossRef] [PubMed]

27. Jakob, F.; Stahl, L.; Vogel, R.F. $\beta$-Glucan Formation Is a Selective Advantage for Beer-Spoiling Levilactobacillus brevis TMW 1.2112 during Planktonic Growth. Microbiol. Res. 2021, 243, 126648. [CrossRef]

28. Garai-Ibabe, G.; Dueñas, M.T.; Irastorza, A.; Sierra-Filardi, E.; Werning, M.L.; López, P.; Corbí, A.L.; Fernández de Palencia, P. Naturally Occurring 2-Substituted (1,3)-Beta-D-Glucan Producing Lactobacillus suebicus and Pediococcus parvulus Strains with Potential Utility in the Production of Functional Foods. Bioresour. Technol. 2010, 101, 9254-9263. [CrossRef]

29. Notararigo, S.; Nácher-Vázquez, M.; Ibarburu, I.; Werning, M.L.; de Palencia, P.F.; Dueñas, M.T.; Aznar, R.; López, P.; Prieto, A. Comparative Analysis of Production and Purification of Homo- and Hetero-Polysaccharides Produced by Lactic Acid Bacteria. Carbohydr. Polym. 2013, 93, 57-64. [CrossRef]

30. Dueñas-Chasco, M.T.; Rodríguez-Carvajal, M.A.; Tejero-Mateo, P.; Espartero, J.L.; Irastorza-Iribas, A.; Gil-Serrano, A.M. Structural Analysis of the Exopolysaccharides Produced by Lactobacillus spp. G-77. Carbohydr. Res. 1998, 307, 125-133. [CrossRef]

31. Koirala, P.; Maina, N.H.; Nihtilä, H.; Katina, K.; Coda, R. Brewers' Spent Grain as Substrate for Dextran Biosynthesis by Leuconostoc pseudomesenteroides DSM20193 and Weissella confusa A16. Microb. Cell. Fact. 2021, 20, 23. [CrossRef]

32. Zhou, Q.; Feng, F.; Yang, Y.; Zhao, F.; Du, R.; Zhou, Z.; Han, Y. Characterization of a Dextran Produced by Leuconostoc pseudomesenteroides XG5 from Homemade Wine. Int. J. Biol. Macromol. 2018, 107, 2234-2241. [CrossRef]

33. Montersino, S.; Prieto, A.; Muñoz, R.; Rivas, B.D.L. Evaluation of Exopolysaccharide Production by Leuconostoc mesenteroides Strains Isolated from Wine. J. Food Sci. 2008, 73, M196-M199. [CrossRef] [PubMed]

34. Dimopoulou, M.; Raffenne, J.; Claisse, O.; Miot-Sertier, C.; Iturmendi, N.; Moine, V.; Coulon, J.; Dols-Lafargue, M. Oenococcus oeni Exopolysaccharide Biosynthesis, a Tool to Improve Malolactic Starter Performance. Front. Microbiol. 2018, 9, 1276. [CrossRef]

35. Dimopoulou, M.; Vuillemin, M.; Campbell-Sills, H.; Lucas, P.M.; Ballestra, P.; Miot-Sertier, C.; Favier, M.; Coulon, J.; Moine, V.; Doco, T.; et al. Exopolysaccharide (EPS) Synthesis by Oenococcus oeni: From Genes to Phenotypes. PLoS ONE 2014, 9, e98898. [CrossRef] [PubMed]

36. Bastard, A.; Coelho, C.; Briandet, R.; Canette, A.; Gougeon, R.; Alexandre, H.; Guzzo, J.; Weidmann, S. Effect of Biofilm Formation by Oenococcus oeni on Malolactic Fermentation and the Release of Aromatic Compounds in Wine. Front. Microbiol. 2016, 7, 613. [CrossRef]

37. Ibarburu, I.; Puertas, A.I.; Berregi, I.; Rodríguez-Carvajal, M.A.; Prieto, A.; Dueñas, M.T. Production and Partial Characterization of Exopolysaccharides Produced by Two Lactobacillus suebicus Strains Isolated from Cider. Int. J. Food Microbiol. 2015, $214,54-62$. [CrossRef] [PubMed]

38. Dimopoulou, M.; Lonvaud-Funel, A.; Dols-Lafargue, M. Polysaccharide Production by Grapes Must and Wine Microorganisms. In Biology of Microorganisms on Grapes, in Must and in Wine; König, H., Unden, G., Fröhlich, J., Eds.; Springer International Publishing: Cham, Switzerland, 2017; pp. 293-314. ISBN 978-3-319-60021-5.

39. Dueñas-Chasco, M.T.; Rodríguez-Carvajal, M.A.; Mateo, P.T.; Franco-Rodríguez, G.; Espartero, J.L.; Irastorza-Iribas, A.; GilSerrano, A.M. Structural Analysis of the Exopolysaccharide Produced by Pediococcus damnosus 2.6. Carbohydr. Res. 1997, 303, 453-458. [CrossRef]

40. Puertas, A.I.; Ibarburu, I.; Elizaquivel, P.; Zuriarrain, A.; Berregi, I.; López, P.; Prieto, A.; Aznar, R.; Dueñas, M.T. Disclosing Diversity of Exopolysaccharide-Producing Lactobacilli from Spanish Natural Ciders. LWT 2018, 90, 469-474. [CrossRef]

41. Dimopoulou, M.; Hazo, L.; Dols-Lafargue, M. Exploration of Phenomena Contributing to the Diversity of Oenococcus oeni Exopolysaccharides. Int. J. Food Microbiol. 2012, 153, 114-122. [CrossRef]

42. Stivala, M.G.; Villecco, M.B.; Enriz, D.; Fernández, P.A. Effect of Phenolic Compounds on Viability of Wine Spoilage Lactic Acid Bacteria. A Structure-Activity Relationship Study. Am. J. Enol. Vitic. 2017, 68, 228-233. [CrossRef]

43. Dols-Lafargue, M.; Gindreau, E.; Le Marrec, C.; Chambat, G.; Heyraud, A.; Lonvaud-Funel, A. Changes in Red Wine Soluble Polysaccharide Composition Induced by Malolactic Fermentation. J. Agric. Food Chem. 2007, 55, 9592-9599. [CrossRef]

44. Ciezack, G.; Hazo, L.; Chambat, G.; Heyraud, A.; Lonvaud-Funel, A.; Dols-Lafargue, M. Evidence for Exopolysaccharide Production by Oenococcus oeni Strains Isolated from Non-Ropy Wines. J. Appl. Microbiol. 2010, 108, 499-509. [CrossRef]

45. Ryan, P.M.; Ross, R.P.; Fitzgerald, G.F.; Caplice, N.M.; Stanton, C. Sugar-Coated: Exopolysaccharide Producing Lactic Acid Bacteria for Food and Human Health Applications. Food Funct. 2015, 6, 679-693. [CrossRef]

46. Weidenmaier, C.; Peschel, A. Teichoic Acids and Related Cell-Wall Glycopolymers in Gram-Positive Physiology and Host Interactions. Nat. Rev. Microbiol. 2008, 6, 276-287. [CrossRef]

47. Chapot-Chartier, M.-P. Interactions of the Cell-Wall Glycopolymers of Lactic Acid Bacteria with Their Bacteriophages. Front. Microbiol. 2014, 5, 236. [CrossRef]

48. Fernández de Palencia, P.; Werning, M.L.; Sierra-Filardi, E.; Dueñas, M.T.; Irastorza, A.; Corbí, A.L.; López, P. Probiotic Properties of the 2-Substituted (1,3)- $\beta$-d-Glucan-Producing Bacterium Pediococcus parvulus 2.6. Appl. Environ. Microbiol. 2009, 75, $4887-4891$. [CrossRef]

49. Kolkman, M.A.; Morrison, D.A.; Van Der Zeijst, B.A.; Nuijten, P.J. The Capsule Polysaccharide Synthesis Locus of Streptococcus pneumoniae Serotype 14: Identification of the Glycosyl Transferase Gene Cps14E. J. Bacteriol. Res. 1996, 178, 3736-3741. [CrossRef]

50. Kolkman, M.A.; van der Zeijst, B.A.; Nuijten, P.J. Functional Analysis of Glycosyltransferases Encoded by the Capsular Polysaccharide Biosynthesis Locus of Streptococcus pneumoniae Serotype 14. J. Biol. Chem. 1997, 272, 19502-19508. [CrossRef] [PubMed] 
51. Stingele, F.; Lemoine, J.; Neeser, J.-R. Lactobacillus Helveticus Lh59 Secretes an Exopolysaccharide That Is Identical to the One Produced by Lactobacillus helveticus TN-4, a Presumed Spontaneous Mutant of Lactobacillus helveticus TY1-2. Carbohydr. Res. 1997, 302, 197-202. [CrossRef]

52. Stingele, F.; Vincent, S.J.; Faber, E.J.; Newell, J.W.; Kamerling, J.P.; Neeser, J.R. Introduction of the Exopolysaccharide Gene Cluster from Streptococcus thermophilus Sfi6 into Lactococcus lactis MG1363: Production and Characterization of an Altered Polysaccharide. Mol. Microbiol. 1999, 32, 1287-1295. [CrossRef] [PubMed]

53. De Vuyst, L.; De Vin, F.; Vaningelgem, F.; Degeest, B. Recent Developments in the Biosynthesis and Applications of Heteropolysaccharides from Lactic Acid Bacteria. Int. Dairy J. 2001, 11, 687-707. [CrossRef]

54. Lebeer, S.; Verhoeven, T.L.A.; Francius, G.; Schoofs, G.; Lambrichts, I.; Dufrêne, Y.; Vanderleyden, J.; De Keersmaecker, S.C.J. Identification of a Gene Cluster for the Biosynthesis of a Long, Galactose-Rich Exopolysaccharide in Lactobacillus rhamnosus GG and Functional Analysis of the Priming Glycosyltransferase. Appl. Environ. Microbiol. 2009, 75, 3554-3563. [CrossRef]

55. Monsan, P.; Bozonnet, S.; Albenne, C.; Joucla, G.; Willemot, R.-M.; Remaud-Siméon, M. Homopolysaccharides from Lactic Acid Bacteria. Int. Dairy J. 2001, 11, 675-685. [CrossRef]

56. Lombard, V.; Golaconda Ramulu, H.; Drula, E.; Coutinho, P.M.; Henrissat, B. The Carbohydrate-Active Enzymes Database (CAZy) in 2013. Nucleic Acids Res. 2014, 42, D490-D495. [CrossRef] [PubMed]

57. Moulis, C.; Joucla, G.; Harrison, D.; Fabre, E.; Potocki-Veronese, G.; Monsan, P.; Remaud-Simeon, M. Understanding the Polymerization Mechanism of Glycoside-Hydrolase Family 70 Glucansucrases. J. Biol. Chem. 2006, 281, 31254-31267. [CrossRef] [PubMed]

58. Vuillemin, M.; Grimaud, F.; Claverie, M.; Rolland-Sabaté, A.; Garnier, C.; Lucas, P.; Monsan, P.; Dols-Lafargue, M.; RemaudSiméon, M.; Moulis, C. A Dextran with Unique Rheological Properties Produced by the Dextransucrase from Oenococcus kitaharae DSM 17330. Carbohydr. Polym. 2018, 179, 10-18. [CrossRef] [PubMed]

59. Llull, D.; Muñoz, R.; López, R.; García, E. A Single Gene (Tts) Located Outside the Cap Locus Directs the Formation of Streptococcus pneumoniae Type 37 Capsular Polysaccharide. Type 37 Pneumococci Are Natural, Genetically Binary Strains. J. Exp. Med. 1999, 190, 241-251. [CrossRef]

60. Whitfield, C. Biosynthesis and Assembly of Capsular Polysaccharides in Escherichia coli. Annu. Rev. Biochem. 2006, 75, 39-68. [CrossRef]

61. Dimopoulou, M.; Claisse, O.; Dutilh, L.; Miot-Sertier, C.; Ballestra, P.; Lucas, P.M.; Dols, M. Molecular Cloning, Expression and Characterization of Oenococcus oeni Priming Glycosyltransferases. Mol. Biotechnol. 2017, 59, 323-333. [CrossRef]

62. Gänzle, M.G.; Zhang, C.; Monang, B.-S.; Lee, V.; Schwab, C. Novel Metabolites from Cereal-Associated Lactobacilli-Novel Functionalities for Cereal Products? Food Microbiol. 2009, 26, 712-719. [CrossRef]

63. Lonvaud-Funel, A.; Joyeux, A. Antagonism between Lactic Acid Bacteria of Wines: Inhibition of Leuconostoc oenos by Lactobacillus plantarum and Pediococcus pentosaceus. Food Microbiol. 1993, 10, 411-419. [CrossRef]

64. Pluvinet, A.; Charron-Bourgoin, F.; Morel, C.; Decaris, B. Polymorphism of Eps Loci in Streptococcus thermophilus: Sequence Replacement by Putative Horizontal Transfer in S. thermophilus IP6757. Int. Dairy J. 2004, 14, 627-634. [CrossRef]

65. Bentley, S.D.; Aanensen, D.M.; Mavroidi, A.; Saunders, D.; Rabbinowitsch, E.; Collins, M.; Donohoe, K.; Harris, D.; Murphy, L.; Quail, M.A.; et al. Genetic Analysis of the Capsular Biosynthetic Locus from All 90 Pneumococcal Serotypes. PLoS Genet. 2006, 2, e31. [CrossRef]

66. Milkman, R.; Jaeger, E.; McBride, R.D. Molecular Evolution of the Escherichia coli Chromosome. VI. Two Regions of High Effective Recombination. Genetics 2003, 163, 475-483. [CrossRef] [PubMed]

67. Cieslewicz, M.J.; Chaffin, D.; Glusman, G.; Kasper, D.; Madan, A.; Rodrigues, S.; Fahey, J.; Wessels, M.R.; Rubens, C.E. Structural and Genetic Diversity of Group B Streptococcus Capsular Polysaccharides. Infect. Immun. 2005, 73, 3096-3103. [CrossRef]

68. Mavroidi, A.; Aanensen, D.M.; Godoy, D.; Skovsted, I.C.; Kaltoft, M.S.; Reeves, P.R.; Bentley, S.D.; Spratt, B.G. Genetic Relatedness of the Streptococcus pneumoniae Capsular Biosynthetic Loci. J. Bacteriol. Res. 2007, 189, 7841-7855. [CrossRef] [PubMed]

69. Kubota, T.; Itagaki, M.; Hoshino, C.; Nagata, M.; Morozumi, T.; Kobayashi, T.; Takagi, R.; Yoshie, H. Altered Gene Expression Levels of Matrix Metalloproteinases and Their Inhibitors in Periodontitis-Affected Gingival Tissue. J. Periodontol. 2008, 79, 166-173. [CrossRef] [PubMed]

70. Ramírez-Castrillón, M.; Mendes, S.D.C.; Inostroza-Ponta, M.; Valente, P. (GTG)5 MSP-PCR Fingerprinting as a Technique for Discrimination of Wine Associated Yeasts? PLoS ONE 2014, 9, e105870. [CrossRef]

71. Cotter, P.D.; Hill, C. Surviving the Acid Test: Responses of Gram-Positive Bacteria to Low PH. Microbiol. Mol. Biol. Rev. 2003, 67, 429-453. [CrossRef]

72. Chowdhury, R.; Sahu, G.K.; Das, J. Stress Response in Pathogenic Bacteria. J. Biosci. 1996, 21, 149-160. [CrossRef]

73. Renouf, V.; Falcou, M.; Miot-Sertier, C.; Perello, M.C.; De Revel, G.; Lonvaud-Funel, A. Interactions between Brettanomyces bruxellensis and Other Yeast Species during the Initial Stages of Winemaking. J. Appl. Microbiol. 2006, 100, 1208-1219. [CrossRef]

74. El Khoury, M.; Campbell-Sills, H.; Salin, F.; Guichoux, E.; Claisse, O.; Lucas, P.M. Biogeography of Oenococcus oeni Reveals Distinctive but Nonspecific Populations in Wine-Producing Regions. Appl. Environ. Microbiol. 2017, 83, e02322-16. [CrossRef] [PubMed]

75. Coulon, J.; Houlès, A.; Dimopoulou, M.; Maupeu, J.; Dols-Lafargue, M. Lysozyme Resistance of the Ropy Strain Pediococcus parvulus IOEB 8801 Is Correlated with Beta-Glucan Accumulation around the Cell. Int. J. Food Microbiol. 2012, 159, 25-29. [CrossRef] [PubMed] 
76. Caggianiello, G.; Kleerebezem, M.; Spano, G. Exopolysaccharides Produced by Lactic Acid Bacteria: From Health-Promoting Benefits to Stress Tolerance Mechanisms. Appl. Microbiol. Biotechnol. 2016, 100, 3877-3886. [CrossRef] [PubMed]

77. Deveau, H.; Van Calsteren, M.-R.; Moineau, S. Effect of Exopolysaccharides on Phage-Host Interactions in Lactococcus lactis. Appl. Environ. Microbiol. 2002, 68, 4364-4369. [CrossRef] [PubMed]

78. McCabe, O.; Spinelli, S.; Farenc, C.; Labbé, M.; Tremblay, D.; Blangy, S.; Oscarson, S.; Moineau, S.; Cambillau, C. The Targeted Recognition of Lactococcus lactis Phages to Their Polysaccharide Receptors. Mol. Microbiol. 2015, 96, 875-886. [CrossRef]

79. Russo, P.; López, P.; Capozzi, V.; De Palencia, P.F.; Dueñas, M.T.; Spano, G.; Fiocco, D. Beta-Glucans Improve Growth, Viability and Colonization of Probiotic Microorganisms. Int. J. Mol. Sci. 2012, 13, 6026-6039. [CrossRef]

80. Stack, H.M.; Kearney, N.; Stanton, C.; Fitzgerald, G.F.; Ross, R.P. Association of Beta-Glucan Endogenous Production with Increased Stress Tolerance of Intestinal Lactobacilli. Appl. Environ. Microbiol. 2010, 76, 500-507. [CrossRef]

81. Arena, M.P.; Spano, G.; Fiocco, D. Beta-Glucans and Probiotics. Am. J. Immunol. 2017, 13, 34-44. [CrossRef]

82. Llull, D.; Lopez, R.; Garcia, E. Genetic Bases and Medical Relevance of Capsular Polysaccharide Biosynthesis in Pathogenic Streptococci. Curr. Mol. Med. 2001, 1, 475-491. [CrossRef]

83. Cooper, C.A.; Mainprize, I.L.; Nickerson, N.N. Genetic, Biochemical, and Structural Analyses of Bacterial Surface Polysaccharides. In Prokaryotic Systems Biology; Krogan, P., Nevan, J., Babu, P., Mohan, B., Eds.; Advances in Experimental Medicine and Biology; Springer International Publishing: Cham, Switzerland, 2015; pp. 295-315. ISBN 978-3-319-23603-2.

84. Brooker, B.E. Ultrastructural Surface Changes Associated with Dextran Synthesis by Leuconostoc mesenteroides. J. Bacteriol. Res. 1977, 131, 288-292. [CrossRef]

85. Nguyen, P.-T.; Nguyen, T.-T.; Bui, D.-C.; Hong, P.-T.; Hoang, Q.-K.; Nguyen, H.-T. Exopolysaccharide Production by Lactic Acid Bacteria: The Manipulation of Environmental Stresses for Industrial Applications. AIMS Microbiol. 2020, 6, 451-469. [CrossRef]

86. Tada, S.; Katakura, Y.; Ninomiya, K.; Shioya, S. Fed-Batch Coculture of Lactobacillus kefiranofaciens with Saccharomyces cerevisiae for Effective Production of Kefiran. J. Biosci. Bioeng. 2007, 103, 557-562. [CrossRef]

87. Polak-Berecka, M.; Waśko, A.; Paduch, R.; Skrzypek, T.; Sroka-Bartnicka, A. The Effect of Cell Surface Components on Adhesion Ability of Lactobacillus rhamnosus. Antonie Van Leeuwenhoek 2014, 106, 751-762. [CrossRef]

88. Wang, C.; Mas, A.; Esteve-Zarzoso, B. The Interaction between Saccharomyces cerevisiae and Non-Saccharomyces Yeast during Alcoholic Fermentation Is Species and Strain Specific. Front. Microbiol. 2016, 7, 502. [CrossRef] [PubMed]

89. da Silva, L.A.; Lopes Neto, J.H.P.; Cardarelli, H.R. Safety and Probiotic Functionality of Isolated Goat Milk Lactic Acid Bacteria. Ann. Microbiol. 2019, 69, 1497-1505. [CrossRef]

90. Mah, T.-F.C.; O'Toole, G.A. Mechanisms of Biofilm Resistance to Antimicrobial Agents. Trends Microbiol. 2001, 9, 34-39. [CrossRef]

91. Dimopoulou, M.; Kefalloniti, V.; Tsakanikas, P.; Papanikolaou, S.; Nychas, G.-J.E. Assessing the Biofilm Formation Capacity of the Wine Spoilage Yeast Brettanomyces bruxellensis through FTIR Spectroscopy. Microorganisms 2021, 9, 587. [CrossRef] [PubMed]

92. Nácher-Vázquez, M.; Iturria, I.; Zarour, K.; Mohedano, M.L.; Aznar, R.; Pardo, M.Á.; López, P. Dextran Production by Lactobacillus Sakei MN1 Coincides with Reduced Autoagglutination, Biofilm Formation and Epithelial Cell Adhesion. Carbohydr. Polym. 2017, 168, 22-31. [CrossRef] [PubMed]

93. Re, B.D.; Sgorbati, B.; Miglioli, M.; Palenzona, D. Adhesion, Autoaggregation and Hydrophobicity of 13 Strains of Bifidobacterium longum. Lett. Appl. Microbiol. 2000, 31, 438-442. [CrossRef]

94. Pérez, P.F.; Minnaard, Y.; Disalvo, E.A.; De Antoni, G.L. Surface Properties of Bifidobacterial Strains of Human Origin. Appl. Environ. Microbiol. 1998, 64, 21-26. [CrossRef] [PubMed]

95. van de Guchte, M.; Serror, P.; Chervaux, C.; Smokvina, T.; Ehrlich, S.D.; Maguin, E. Stress Responses in Lactic Acid Bacteria. Antonie Van Leeuwenhoek 2002, 82, 187-216. [CrossRef]

96. Lonvaud-Funel, A.; Joyeux, A.; Desens, C. Inhibition of Malolactic Fermentation of Wines by Products of Yeast Metabolism. J. Sci. Food Agric. 1988, 44, 183-191. [CrossRef]

97. Bockwoldt, J.A.; Stahl, L.; Ehrmann, M.A.; Vogel, R.F.; Jakob, F. Persistence and $\beta$-Glucan Formation of Beer-Spoiling Lactic Acid Bacteria in Wheat and Rye Sourdoughs. Food Microbiol. 2020, 91, 103539. [CrossRef]

98. Delaherche, A.; Claisse, O.; Lonvaud-Funel, A. Detection and Quantification of Brettanomyces bruxellensis and "ropy" Pediococcus damnosus Strains in Wine by Real-Time Polymerase Chain Reaction. J. Appl. Microbiol. 2004, 97, 910-915. [CrossRef]

99. Martínez Viedma, P.; Abriouel, H.; Sobrino López, A.; Ben Omar, N.; Lucas López, R.; Valdivia, E.; Martín Belloso, O.; Gálvez, A. Effect of Enterocin AS-48 in Combination with High-Intensity Pulsed-Electric Field Treatment against the Spoilage Bacterium Lactobacillus diolivorans in Apple Juice. Food Microbiol. 2009, 26, 491-496. [CrossRef]

100. Pataro, G.; Barca, G.M.J.; Donsì, G.; Ferrari, G. On the Modeling of Electrochemical Phenomena at the Electrode-Solution Interface in a PEF Treatment Chamber: Methodological Approach to Describe the Phenomenon of Metal Release. J. Food Eng. 2015, 165, 34-44. [CrossRef]

101. Van Wyk, S.; Silva, F.V.M.; Farid, M.M. Pulsed Electric Field Treatment of Red Wine: Inactivation of Brettanomyces and Potential Hazard Caused by Metal Ion Dissolution. Innov. Food Sci. Emerg. Technol. 2019, 52, 57-65. [CrossRef]

102. Pérez-Serradilla, J.A.; de Castro, M.D.L. Role of Lees in Wine Production: A Review. Food Chem. 2008, 111, 447-456. [CrossRef] [PubMed]

103. Vidal, S.; Williams, P.; Doco, T.; Moutounet, M.; Pellerin, P. The Polysaccharides of Red Wine: Total Fractionation and Characterization. Carbohydr. Polym. 2003, 54, 439-447. [CrossRef] 
104. Samant, S.K.; Singhal, R.S.; Kulkarni, P.R.; Rege, D.V. Protein-Polysaccharide Interactions: A New Approach in Food Formulations. Int. J. Food Sci. 1993, 28, 547-562. [CrossRef]

105. Moine-Ledoux, V.; Dubourdieu, D. An Invertase Fragment Responsible for Improving the Protein Stability of Dry White Wines. J. Sci. Food Agric. 1999, 79, 537-543. [CrossRef]

106. Taira, S.; Ono, M.; Matsumoto, N. Reduction of Persimmon Astringency by Complex Formation between Pectin and Tannins. Postharvest Biol. Technol. 1997, 12, 265-271. [CrossRef]

107. Moine-Ledoux, V.; Dubourdieu, D. Role of yeast mannoproteins with regard to tartaric stabilization of wines. Bull. L'oiv 2002, 75, 471-482.

108. Guise, R.; Filipe-Ribeiro, L.; Nascimento, D.; Bessa, O.; Nunes, F.M.; Cosme, F. Comparison between Different Types of Carboxylmethylcellulose and Other Oenological Additives Used for White Wine Tartaric Stabilization. Food Chem. 2014, 156, 250-257. [CrossRef]

109. Martínez-Lapuente, L.; Guadalupe, Z.; Ayestarán, B. Properties of Wine Polysaccharides; IntechOpen: London, UK, 2019; ISBN 9781-78984-072-8.

110. Gonçalves, F.J.; Fernandes, P.A.R.; Wessel, D.F.; Cardoso, S.M.; Rocha, S.M.; Coimbra, M.A. Interaction of Wine Mannoproteins and Arabinogalactans with Anthocyanins. Food Chem. 2018, 243, 1-10. [CrossRef] [PubMed]

111. Soares, S.; Mateus, N.; de Freitas, V. Carbohydrates Inhibit Salivary Proteins Precipitation by Condensed Tannins. J. Agric. Food Chem. 2012, 60, 3966-3972. [CrossRef]

112. Gonçalves, F.J.; Rocha, S.M.; Coimbra, M.A. Study of the Retention Capacity of Anthocyanins by Wine Polymeric Material. Food Chem. 2012, 134, 957-963. [CrossRef]

113. Cameleyre, M.; Lytra, G.; Barbe, J.-C. Static Headspace Analysis Using Low-Pressure Gas Chromatography and Mass Spectrometry, Application to Determining Multiple Partition Coefficients: A Practical Tool for Understanding Red Wine Fruity Volatile Perception and the Sensory Impact of Higher Alcohols. Anal. Chem. 2018, 90, 10812-10818. [CrossRef] [PubMed]

114. Muñoz-González, C.; Martín-Álvarez, P.J.; Moreno-Arribas, M.V.; Pozo-Bayón, M.Á. Impact of the Nonvolatile Wine Matrix Composition on the in Vivo Aroma Release from Wines. J. Agric. Food Chem. 2014, 62, 66-73. [CrossRef]

115. Dufour, C.; Bayonove, C.L. Influence of Wine Structurally Different Polysaccharides on the Volatility of Aroma Substances in a Model System. J. Agric. Food Chem. 1999, 47, 671-677. [CrossRef] [PubMed] 